\title{
Prepartum administration of recombinant bovine somatotropin (rBST) on adaptation to subclinical ketosis of the ewes and performance of the lambs
}

\author{
[Administração pré-parto de somatotropina bovina recombinante (rBST) na adaptação da \\ cetose subclínica de ovelhas e no desempenho dos cordeiros] \\ J.O. Feijó ${ }^{1}$, A. Schneider ${ }^{1}$, E. Schmitt ${ }^{1,2}$, C.C. Brauner ${ }^{1}$, C.F. Martins ${ }^{1}$, M. Barbosa-Ferreira ${ }^{3}$, \\ F.A.B. Del Pino ${ }^{l}$, S.P. Faria Junior ${ }^{4}$, V.R. Rabassa ${ }^{l}$, M.N. Corrêa ${ }^{1 *}$ \\ ${ }^{1}$ Faculdade de Veterinária - Universidade Federal de Pelotas - UFPel - Pelotas, RS \\ ${ }^{2}$ Embrapa CPAF - Porto Velho, RO \\ ${ }^{3}$ Universidade Anhanguera-Uniderp - Campo Grande, MS \\ ${ }^{4}$ MSD - Saúde Animal - São Paulo, SP
}

\begin{abstract}
The aim of this study was to determine the effect of prepartum rbST injection on the metabolic profile of pregnant ewes induced to subclinical ketosis, as well as the metabolism until seven days of life and weight gain until seven weeks of life of the lambs. Twenty seven pregnant ewes of the pantaneiro genetic group were used, divided into two groups: $\operatorname{rbST}$ group $(n=14)$ and control group $(n=13)$. The rbST group received two applications of $1 \mathrm{mg} / \mathrm{kg}$ of rbST, at 97 and 111 days gestation, while the control group received placebo injections. There were significant differences between groups in levels of GGT in the ketosis post induction period and BHB concentrations in the postpartum period. Concentrations of glucose, urea, phosphorus, albumin, cholesterol, AST, NEFA and insulin were not different between dams from the two groups in different periods of the study $(\mathrm{P}>0.05)$. There was an effect of rbST on body weight observed already at fourteen days of life $(\mathrm{P}<0.0001)$, there was an increase in serum phosphorus levels at birth of lambs $(\mathrm{P}=0.0014)$, and albumin at seven days of life $(\mathrm{P}=0.0014)$ of the lambs, with no difference between groups for the other metabolites. Therefore, the use of rbST was effective in increasing the weight of the lambs until the seventh week of life. In addition, rbST treatment had positive effects on the dam metabolism with reduction of liver overload, as indicated by decreased GGT after ketosis induction and decreased BHB at the postpartum period.
\end{abstract}

Keywords: sheep, growth hormone, ketosis, pregnancy toxemia

\section{RESUMO}

O objetivo deste estudo foi determinar o efeito da administração pré-parto de rbST sobre o perfil metabólico de ovelhas induzidas à cetose subclínica, assim como sobre o metabolismo até sete dias de vida e ganho de peso até sete semanas de vida dos cordeiros. Vinte e sete ovelhas prenhas do grupo genético pantaneiro foram divididas em dois grupos: grupo rbST $(n=14)$ e grupo controle $(n=13)$. $O$ grupo rbST recebeu duas aplicações de $1 \mathrm{mg} / \mathrm{kg}$ de rbST, aos 97 e 111 dias de gestação, ao passo que o grupo controle recebeu injeções de placebo. Houve diferenças significativas entre os grupos nos níveis de GGT no período de pós-indução de cetose e concentrações de BHB no período pós-parto. As concentrações de glicose, ureia, fósforo, albumina, colesterol, AST, NEFA e insulina não foram diferentes entre os grupos nos diferentes periodos do estudo $(P>0,05)$. Houve um efeito de rbST no peso corporal dos cordeiros já observado nos 14 dias de vida $(P<0,0001)$, verificou-se um aumento dos níveis séricos de fósforo ao nascimento de cordeiros $(P=0,0014)$ e albumina de sete dias de vida $(P=0,0014), e$ não houve diferença entre os grupos para os outros metabólitos. Portanto, a utilização de rbST foi eficaz. em aumentar o peso dos cordeiros até a sétima semana de vida. Além disso, a aplicação de rbST teve

Recebido em 13 de maio de 2013

Aceito em 18 de junho de 2014

*Autor para correspondência (corresponding author)

E-mail: marcio.nunescorrea@gmail.com 
efeitos positivos no metabolismo com a redução da sobrecarga do fígado, como indicado pela diminuição da GGT após a indução da cetose e diminuição de BHB no período pós-parto.

\section{Palavras-chave: ovinos, hormônio do crescimento, cetose, toxemia da prenhez}

\section{INTRODUCTION}

Ketosis or pregnancy toxemia is one of the most significant causes of mortality of ewes and occurs in late gestation (Sargison, 2007). On the other hand, subclinical ketosis occurs mainly within the first two weeks postpartum (Harmeyer and Schlumbohm, 2008) up to 6 weeks postpartum. The prevalence ranges from 31 to $41 \%$ in ewes. Ovine pregnancy toxemia results from a failure of dietary energy and gluconeogenesis to provide enough glucose to meet the increasing fetal demands in the last 6 weeks of gestation (Andrews et al., 1996). This condition can lead to hypoglycemia and excessive mobilization of body fat, which can increase circulating concentrations of ketone bodies (beta-hydroxybutyrate; BHB) and lead to the development of fatty liver (Dante et al., 1995). Besides hyperketonemia, elevated concentrations of non-esterified fatty acids (NEFA) and hypoglycemia represent typical serum profiles of ewes with pregnancy toxaemia (Harmeyer and Schlumbohm, 2006).

The injection of bovine recombinant somatotropin (rbST) or growth hormone $(\mathrm{GH})$ has been used as a strategy to prevent ketosis by adapting the ewe to the high amount of lipid mobilization (McGuffey et al., 1991). In dairy cows, when injected in the prepartum period, rbST increases blood glucose and IGF-I concentrations in the prepartum period and reduces NEFA concentrations during the postpartum period, which results in increased dry matter intake and milk production (Putnam et al., 1999; Pauletti et al., 2005; Schneider et al., 2011). Moreover, Stelwagen et al. (1993) demonstrated that there is a positive effect of $\mathrm{GH}$ prepartum rbST injection on mammary gland development and milk production in sheep, due to increased cell proliferation stimulated by the IGF-I produced in response to rbST.

The intensification of sheep production systems focusing on meat lamb has increased and understanding the effects of alternatives aiming to prevent diseases in the flock are important to increase production levels. To our knowledge there is no previous investigation regarding rbST use during the prepartum period in ewes aiming to promote better metabolic adaptation at lambing. Based on these, the aim of this study was to determine the prepartum effect of rbST on the metabolic profile of ewes induced to subclinical ketosis, as well as on the metabolism and early performance of lambs.

\section{MATERIAL AND METHODS}

This study was approved by the Ethics Committee on Animal Experimentation at University Federal of Pelotas, registered under the number 7933, and was held at The Sheep Husbandry Technology Centre, located in Três Barras Farm School of the University ANHANGUERA / UNIDERP, in Campo Grande- MS, Brazil. Twenty seven ewes, 2 to 4 years old, of the pantaneiro genetic group were used. The average body weight (BW) was $40 \pm 5$ $\mathrm{kg}$ and the body condition score was between 2.0 and 3.0 at the beginning of the experiment (in a five point scale; Russel et al., 1969).

Ewes were divided into two groups: rbST ( $\mathrm{n}=$ 14) and control group $(n=13)$. The rbST group received two applications of $1 \mathrm{mg} / \mathrm{kg}$ of $\mathrm{BW}$ of rbST (500 mg Boostin $®$, Schering-Plough, Brazil) at 97 and 111 days of gestation, whereas the control group received two doses of a sodium chloride solution $0.9 \%$ as placebo.

For the first 103 days of gestation animals were kept grazing in a pasture thay consisted of Brachiaria spp. Starting on day 104 a commercial concentrated ration was added to the diet (Nutri ovinos confinamento - Agrolima nutrição Animal, Campo Grande, MS, Brazil (Table 1)) at $1 \%$ of BW. One week after, the concentrate level was increased to $2 \%$ of $\mathrm{BW}$. From days 132 to 136 of gestation ewes were submitted to food restriction, calculated to meet only $30 \%$ of the needs in dry matter basis, according to NRC (1985). During this period, feed consisted of millet silage. After the restriction period the basic diet of Brachiaria spp. and concentrate in an amount of $2 \%$ of BW was fed again. 
Blood samples were collected every seven days, from day 90 of gestation until day 132 prepartum (pre-induction). During feed restriction (days 132 to 136 of gestation), blood samples were collected twice a day. From day 136 until the parturition (post-induction period) blood samples were collected every 3 days.

Table 1. Chemical composition of the commercial supplement

\begin{tabular}{lc}
\hline Component & Quantity \\
\hline Dry matter & $120 \mathrm{~g} / \mathrm{kg}$ \\
Crude protein & $125 \mathrm{~g} / \mathrm{kg}$ \\
Non-protein nitrogen & $14.40 \mathrm{~g} / \mathrm{kg}$ \\
Fiber & $150 \mathrm{~g} / \mathrm{kg}$ \\
Mineral & $43 \mathrm{~g} / \mathrm{kg}$ \\
Calcium & $8.300 \mathrm{mg} / \mathrm{kg}$ \\
Phosphorus & $3.000 \mathrm{mg} / \mathrm{kg}$ \\
Cobalt & $0.40 \mathrm{mg} / \mathrm{kg}$ \\
Magnesium & $50 \mathrm{mg} / \mathrm{kg}$ \\
Selenium & $0.15 \mathrm{mg} / \mathrm{kg}$ \\
\hline
\end{tabular}

The lambling period started at $142 \pm 3$ days of gestation. Blood samples were taken weekly during 8 weeks postpartum. The samples from all animals were collected into two tubes, with EDTA and potassium fluoride for analysis of glucose and one without anticoagulant to obtain serum for further analysis and centrifuged at $1.000 \mathrm{x} g$ for 15 minutes and then cryopreserved at $-80^{\circ} \mathrm{C}$. The concentrations of glucose, total cholesterol, aspartate aminotransferase (AST), albumin, urea, gamma glutamyl transferase (GGT), and phosphorus were evaluated using colorimetric diagnostic kits (Labtest Diagnostica SA, Brazil) measured in a spectrophotometer (FEMTO $435^{\circledR}$, Brazil). Analysis of NEFA and BHB were performed using the micro-method described by Ballou et al. (2009) using commercial kits (Wako USA, Richmond, USA and Ranadox, Oceanside, CA, respectively). The insulin analysis was performed by enzyme immunoassay using a commercial kit (DIAsource ImmunoAssays S.A., KAP1251, Belgium, Europe). Lamb blood was also collected for analysis of the same metabolites described before in addition to total protein (TP)
(Labtest Diagnostica SA, Brazil) in the first 24 hours after birth and seven days later.

The lamb body weight was evaluated at 24 hours of age and then every 7 days for 7 weeks. From the start of rbST injections all animals were monitored daily. During the induction period, clinical evaluation of all females was performed, evaluating the heart and respiratory rate, ruminal movements, rectal temperature, and color of mucous membranes.

The data analysis was performed using the Statistical Analysis System (Statistical..., 1986). The MIXED MODEL procedure was used to compare the means between groups, week and the interaction group*week, that were adjusted with the Tukey test for performance (weight gain) and metabolic parameters (serum glucose, cholesterol, urea, phosphorus, GGT, albumin, NEFA, PPT, AST, BHB and insulin).

\section{RESULTS}

Only one ewe in the control group had signs of clinical ketosis and therefore it was removed from the experiment. There was only single lambing in both groups during this study. There were three pregnancy losses after the induction period, all in the control group, representing a rate of $18.75 \%$ pregnancy loss with the induction of subclinical ketosis. Regarding the metabolic profile of the ewes, the difference between groups was observed only for the liver enzyme GGT during the induction period $(\mathrm{P}=0.01)$ and BHB concentrations in the postpartum period ( $\mathrm{P}$ $=0.30)$. There was no difference between periods for the metabolites measured (Table 2). Body weight of the lambs was higher for the rbST treated group from 2 to 7 weeks of age $(\mathrm{P}<0.0001$; Figure 1). The average daily gain (ADG) for the rbST group was $165 \mathrm{~g}$, while it was $146 \mathrm{~g}$ for the control group $(\mathrm{P}>0.05)$. There was an increase in serum phosphorus concentrations at the birth of lambs $(\mathrm{P}=0.0014)$, and albumin at seven days of life $(\mathrm{P}=0.0014)$. Serum glucose, cholesterol, urea, AST, GGT, and TP concentrations were not different between groups (Table 3). 
Table 2. Serum metabolic profile ( \pm standard error of mean) of ewes submitted to the administration of rbST at 97 and 111 days of gestation and subsequently submitted to induction of subclinical ketosis

\begin{tabular}{|c|c|c|c|c|c|c|c|c|c|c|c|}
\hline \multirow[t]{2}{*}{ Item } & \multicolumn{2}{|c|}{ Pre-induction } & \multicolumn{2}{|c|}{ Induction } & \multicolumn{2}{|c|}{ Post-induction } & \multicolumn{2}{|c|}{ Post-partum } & \multicolumn{3}{|c|}{ P Value } \\
\hline & $\mathrm{rbST}$ & GC* & rbST & GC & $\mathrm{rbST}$ & GC & $\mathrm{rbST}$ & GC & Group & Period & $\begin{array}{l}\text { Group* } \\
\text { Period }\end{array}$ \\
\hline $\begin{array}{l}\text { Glucose } \\
(\mathrm{mg} / \mathrm{dL})\end{array}$ & $\begin{array}{c}57.8 \mathrm{C} \pm \\
2.67\end{array}$ & $\begin{array}{c}56.9 \mathrm{C} \pm \\
2.50\end{array}$ & & $\begin{array}{c}33.6 \mathrm{D} \pm \\
2.05\end{array}$ & 4.06 & 3.8 & $\begin{array}{c}72.7 \mathrm{~B} \pm \\
2.51\end{array}$ & & 0.08 & $<.0001$ & 0.10 \\
\hline & $\begin{array}{c}0.45 \mathrm{D} \pm \\
0.04\end{array}$ & & $\begin{array}{c}\text { 1.3. } \mathrm{A} \pm \\
0.05\end{array}$ & & $\begin{array}{c}0.60 \mathrm{C} \pm \\
0.07\end{array}$ & & & & 0.08 & $<.0001$ & 0,04 \\
\hline $\begin{array}{l}\text { Chol } \\
(\mathrm{mg} /\end{array}$ & $\begin{array}{c}76.2 \mathrm{~B} \pm \\
3.06\end{array}$ & $\begin{array}{c}74.9 \mathrm{~B} \pm \\
3.02\end{array}$ & $\begin{array}{c}89.8 \mathrm{~A} \pm \\
3.41\end{array}$ & $\begin{array}{r}86.6 \mathrm{~A} \\
3.33\end{array}$ & $\begin{array}{c}89.8 \mathrm{~A} \pm \\
4.57\end{array}$ & $\begin{array}{r}93.0 \\
4.6\end{array}$ & $\begin{array}{l}69.4 \mathrm{~B} \pm \\
2.64\end{array}$ & $\begin{array}{c}71.8 \mathrm{~B} \pm \\
2.8\end{array}$ & 0.88 & $<.0001$ & 0.3035 \\
\hline $\begin{array}{l}\text { Urea } \\
(\mathrm{mg} / \mathrm{dL})\end{array}$ & $\begin{array}{c}28.4 \mathrm{~B} \pm \\
1.9\end{array}$ & $\begin{array}{r}27.8 \\
1.9\end{array}$ & $\begin{array}{c}61.5 \mathrm{~A} \pm \\
2.16\end{array}$ & $\begin{array}{c}57.5 \mathrm{~A} \pm \\
2.05\end{array}$ & $\begin{array}{c}28.5 \mathrm{BC} \pm \\
3.34\end{array}$ & $\begin{array}{r}27.2 \mathrm{~B} \\
3.3\end{array}$ & $\begin{array}{c}32.1 \mathrm{C} \pm \\
1.43\end{array}$ & $\begin{array}{c}37.8 \mathrm{C} \pm \\
1.49\end{array}$ & 0.9 & $<.0001$ & 0.0334 \\
\hline & & & & & $\begin{array}{l}2.7 \pm \\
0.31\end{array}$ & & & & 0.28 & 0.6700 & 0.8998 \\
\hline $\begin{array}{l}\text { AST } \\
(\mathrm{U} / \mathrm{L})^{2}\end{array}$ & $\begin{array}{c}83.9 \mathrm{~A} \pm \\
3.07\end{array}$ & $\begin{array}{c}\text { 81.0A } \pm \\
3.19\end{array}$ & $\begin{array}{c}74.9 \mathrm{~B} \pm \\
3.5\end{array}$ & $\begin{array}{c}61.3 \mathrm{~B} \pm \\
3.37\end{array}$ & $\begin{array}{c}63.4 \mathrm{C} \pm \\
4.85\end{array}$ & $\begin{array}{c}63.6 \mathrm{C} \pm \\
4.87\end{array}$ & $\begin{array}{c}56.8 \mathrm{D} \pm \\
2.3\end{array}$ & $\begin{array}{c}\text { 49.3 D } \pm \\
2.7\end{array}$ & 0.4 & $<.0001$ & 0.3682 \\
\hline $\begin{array}{l}\text { GGT } \\
(\mathrm{U} / \mathrm{L})^{3}\end{array}$ & $\begin{array}{c}51.0 \mathrm{C} \pm \\
9.1\end{array}$ & $\begin{array}{c}53.0 \mathrm{C} \pm \\
9.46\end{array}$ & $\begin{array}{c}122.2 \mathrm{~A} \pm \\
10.7\end{array}$ & $\begin{array}{c}140.0 \mathrm{~A} \pm \\
10.4\end{array}$ & $\begin{array}{c}116.6 \mathrm{a} . \mathrm{A} \pm \\
14.8\end{array}$ & $\begin{array}{c}\text { 184.6b.A } \pm \\
14.6\end{array}$ & $\begin{array}{c}164.7 \mathrm{~B} \pm \\
7.5\end{array}$ & $\begin{array}{c}181.9 \mathrm{~B} \pm \\
7.8\end{array}$ & 0.01 & $<.0001$ & 0.0340 \\
\hline & $\begin{array}{c}5.4 \mathrm{~A} \pm \\
0.20\end{array}$ & $\begin{array}{c}5.5 \mathrm{~A} \pm \\
0.20\end{array}$ & $\begin{array}{c}3.9 \mathrm{C} \pm \\
0.22\end{array}$ & $\begin{array}{c}4.4 \mathrm{C} \pm \\
0.21\end{array}$ & $\begin{array}{c}4.1 \mathrm{C} \pm \\
0.32\end{array}$ & $\begin{array}{c}4.3 \mathrm{C} \pm \\
0.33\end{array}$ & $\begin{array}{c}4.7 \mathrm{~B} \pm \\
0.16\end{array}$ & $\begin{array}{c}4.8 \mathrm{~B} \pm \\
0.17\end{array}$ & 0.35 & $<.0001$ & 0.4957 \\
\hline BHB & $\begin{array}{c}0.25 \mathrm{C} \pm \\
0.25\end{array}$ & $\begin{array}{c}0.28 \mathrm{C} \pm \\
0.25\end{array}$ & $\begin{array}{c}1.08 \mathrm{~B} \pm \\
0.29\end{array}$ & $\begin{array}{c}0.53 \mathrm{~B} \pm \\
0.28\end{array}$ & $\begin{array}{c}0.86 \mathrm{AB} \pm \\
0.44\end{array}$ & $\begin{array}{c}1.51 \mathrm{AB} \pm \\
0.47\end{array}$ & $\begin{array}{c}1.35^{\mathrm{a}} . \mathrm{A} \pm \\
0.20\end{array}$ & $\begin{array}{c}2.19 \mathrm{bA} \pm \\
0.21\end{array}$ & 0.30 & $<.0001$ & 0.0127 \\
\hline $\begin{array}{l}\text { Insulin } \\
(\mu \mathrm{UI} / \mathrm{mL})\end{array}$ & $\begin{array}{c}20.8 \mathrm{~A} \pm \\
4.45\end{array}$ & $\begin{array}{c}16.78 \mathrm{~A} \pm \\
41\end{array}$ & $\begin{array}{c}11.72 \mathrm{~B} \pm \\
4.45\end{array}$ & $\begin{array}{c}7.41 \mathrm{~B} \pm \\
4.16\end{array}$ & & & $\begin{array}{c}20.04 \mathrm{~A} \pm \\
4.5\end{array}$ & $\begin{array}{c}12.7 \mathrm{~A} \pm \\
4.27\end{array}$ & 0.38 & $<.0001$ & 0.6362 \\
\hline
\end{tabular}

${ }^{1}$ Non-esterified fatty acids; ${ }^{2}$ Aspartate aminotransferase; ${ }^{3}$ Gamma glutamyl transferase; ${ }^{4}$ beta-hydroxybutyrate $*$ Control Group a.b Lower case letters in the same row indicate statistical difference between groups in the same period $(\mathrm{P}<0.05) .{ }^{\text {A.B }}$ Capital letters in the same row indicate significant differences between periods $(\mathrm{P}<0.05)$.

$\prec$ rbST $\rightarrow$ Control

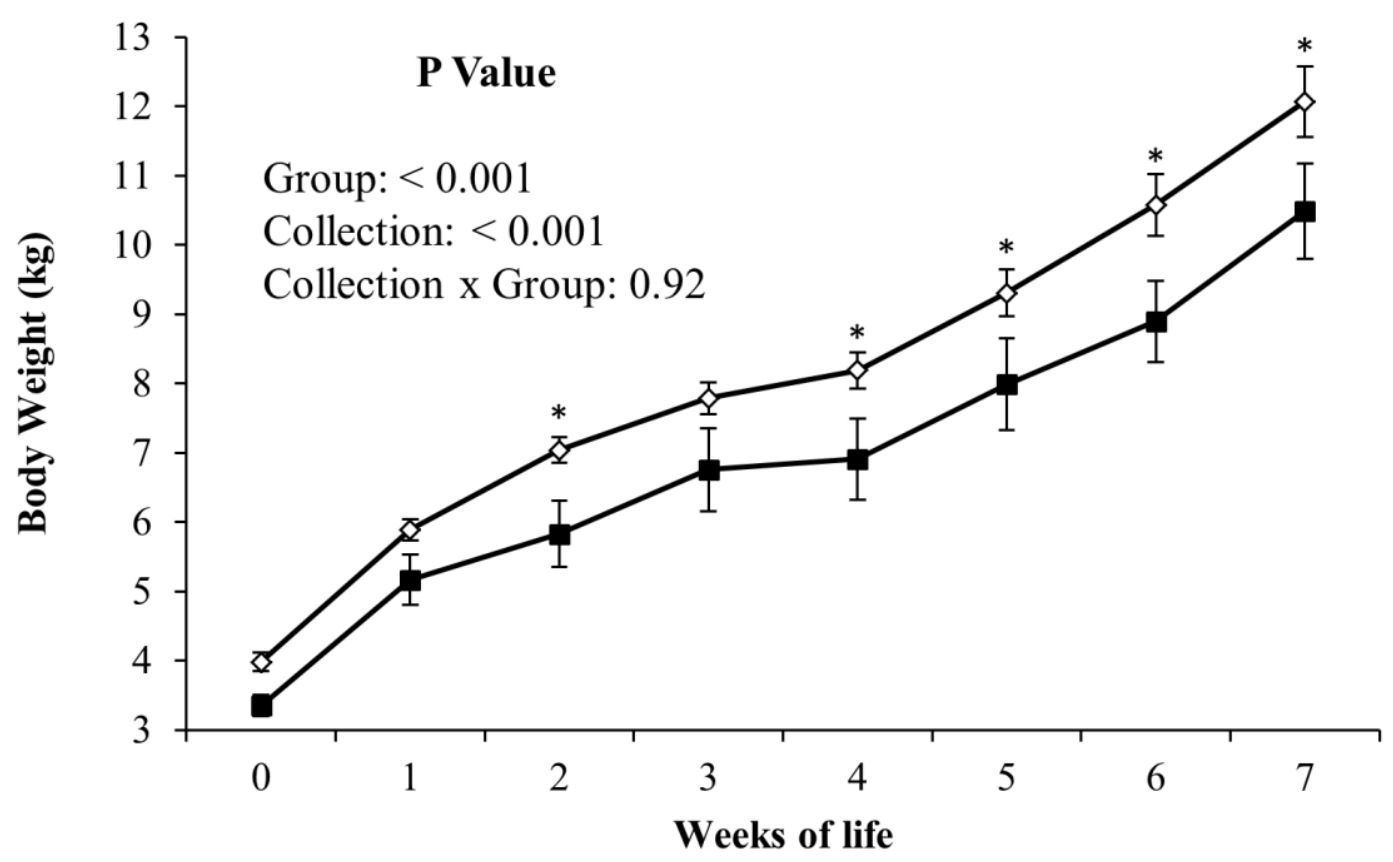

Figure 1. Body weight ( \pm standard deviation) of lambs whose mothers received $\mathrm{rbST}$ and were induced to subclinical ketosis during the pre-partum period (* Indicates significant differences between groups). 
Table 3. Serum metabolic profile ( \pm standard error of mean) of lambs of ewes from bST group and control group at one and seven days of age

\begin{tabular}{|c|c|c|c|c|c|c|c|}
\hline \multirow[t]{2}{*}{ Item } & \multicolumn{2}{|c|}{1 day } & \multicolumn{2}{|c|}{7 days } & \multicolumn{3}{|c|}{ P Value } \\
\hline & $\mathrm{rbST}$ & $\mathrm{GC}^{*}$ & $\mathrm{rbST}$ & $\mathrm{GC}^{*}$ & Group & Period & $\begin{array}{l}\text { Group*Per } \\
\text { iod }\end{array}$ \\
\hline Glucose (mg/dL) & $170.8 \mathrm{~A} \pm 10.61$ & $142.6 \mathrm{~A} \pm 11.07$ & $115.7 \mathrm{~B} \pm 11.54$ & $121.1 \mathrm{~B} \pm 11.57$ & 0.38 & 0.0007 & 0.0954 \\
\hline $\mathrm{NEFA}(\mathrm{mEq} / \mathrm{L})^{1}$ & $2.01 \mathrm{~A} \pm 0.24$ & $1.45 \mathrm{~A} \pm 0.25$ & $0.76 \mathrm{~B} \pm 0.24$ & $0.76 \mathrm{~B} \pm 0.25$ & 0.26 & 0.0002 & 0.2723 \\
\hline Cholesterol (mg/dL) & $114.6 \pm 6.9$ & $106.1 \pm 7.20$ & $120.8 \pm 6.9$ & $114.9 \pm 7.20$ & 0.32 & 0.2990 & 0.8512 \\
\hline Urea $(\mathrm{mg} / \mathrm{dL})$ & $58.3 \mathrm{~A} \pm 4.3$ & $61.6 \mathrm{~A} \pm 4.5$ & $38.7 \mathrm{~B} \pm 4.3$ & $40.3 \mathrm{~B} \pm 4.5$ & 0.62 & $<.0001$ & 0.8364 \\
\hline Albumin (g/dL) & $2.5 \mathrm{~B} \pm 0.10$ & $2.2 \mathrm{~B} \pm 0.11$ & 2.9a.A \pm 0.10 & 2.4b.A \pm 0.11 & 0.001 & 0.0041 & 0.4106 \\
\hline Total Protein $(\mathrm{g} / \mathrm{dL})$ & $9.6 \mathrm{~A} \pm 0.65$ & $8.8 \mathrm{~A} \pm 0.67$ & $8.2 \mathrm{~B} \pm 0.65$ & $7.1 \mathrm{~B} \pm 0.67$ & 0.19 & 0.0261 & 0.8324 \\
\hline $\operatorname{AST}(\mathrm{U} / \mathrm{L})^{2}$ & $107.6 \mathrm{~A} \pm 7.56$ & $88.0 \mathrm{~A} \pm 7.9$ & $63.7 \mathrm{~B} \pm 7.56$ & $54.4 \mathrm{~B} \pm 7.9$ & 0.11 & $<.0001$ & 0.4429 \\
\hline GGT $(\mathrm{U} / \mathrm{L})^{3}$ & $1713.6 \mathrm{~A} \pm 115$ & $1666.2 \mathrm{~A} \pm 120$ & $605.2 \mathrm{~B} \pm 115$ & $532.3 \mathrm{~B} \pm 120$ & 0.65 & $<.0001$ & 0.9003 \\
\hline Phosphorus (mg/dL) & $15.8 \mathrm{a} \pm 0.74$ & $12.2 b \pm 0.78$ & $14.9 \pm 0.74$ & $13.3 \pm 0.78$ & 0.001 & 0.9129 & 0.1639 \\
\hline
\end{tabular}

${ }^{1}$ Non-esterified fatty acids; ${ }^{2}$ Aspartate aminotransferase; ${ }^{3}$ Gamma-glutamyl transferase; * Control Group.

${ }^{a . b}$ Lower case letters in the same row indicate statistical difference between groups in the same period $(\mathrm{P}<0.05)$.

${ }^{\text {A.B }}$ Capital letters in the same row indicate significant differences between periods $(\mathrm{P}<0.05)$.

\section{DISCUSSION}

It was observed that prepartum administration of rbST did not affect most of the blood biochemical parameters analyzed in pregnant ewes. An important finding was the decreased blood concentrations of $\beta$-hydroxybutyrate and liver enzyme gamma glutamil transferase in the post induction of subclinical ketosis, which indicates a better metabolic adaptation in these ewes. Moreover, the greater body weight gain of lambs from dams receiving rbST in prepartum was also very relevant, observed already in the second week of life, which is probably due to better milk production of these dams.

During the induction of ketosis an increase in serum BHB was observed for all ewes, confirming the occurrence of ketosis subclinical (BHB blood levels above $0.5 \mathrm{mmol} / \mathrm{L}$ ). Among the ketones, the BHB is undoubtedly the most widely used as an indicator of ketosis, due to its stability in serum (Caldeira, 2005). Fasting induces a significant increase in blood levels of ketone bodies (Caldeira, 2005), which were increased during the induction period in this study. From the data obtained in this study we found that the group that received prepartum doses of rbST BHB levels were lower than in the control group, thus highlighting that the administration of rbST may promote adaptation to lipid mobilization, decreasing levels of ketone bodies in the postpartum period, and therefore may be an alternative for prevention of ketosis in ruminants. This achievement occurs because the $\mathrm{GH}$ or rbST induces lipid mobilization (Gulay et al., 2004), so the ewes which received prepartum
rbST during induction of ketosis were already adapted for using the NEFA produced by lipolysis as a source of energy and therefore produced less $\mathrm{BHB}$, reducing its adverse effects on animal performance and health of the fetus. With the administration of rbST in the prepartum of ewes it was possible to observe changes in the activity of the enzyme GGT after induction of sub-clinical ketosis. It is important to note that the level of GGT in the rbST group was lower than in the control group, thus emphasizing the positive effect of rbST in reducing liver damage due to excessive lipid mobilization (Schneider $e t$ al., 2011), after induction of subclinical ketosis.

Concentrations of the NEFA are related to the mobilization of fat from adipose tissue, being under the direct influence of growth hormone $(\mathrm{GH})$. In vitro results demonstrate that GH decreases drastically lipogenesis during treatment with bST (Dante et al., 1995). However, in this study, although two applications of rbST occurred in a 14 day interval, there was no effect of rbST treatment on concentrations of NEFA. However, we observed increased levels of NEFA during food restriction, further confirming the occurrence of sub-clinical ketosis.

Lambs born from sows that received prepartum injections of rbST had greater body weight at 14 days of life, despite having a similar weight at birth. Thus, the positive effect of prepartum rbST on lactogenesis mamogenesis observed in previous studies may explain this result, since the larger tissue proliferation of mammary parenchyma, caused by high levels of IGF-I in 
response to rbST, allows increased milk production during the subsequent lactation (Stelwagen et al., 1993; Schneider et al., 2011). This effect is confirmed by the absence of significant difference between groups at birth, indicating that the difference was obtained during the development of the lambs by greater body weight gain in the first days of life. This largest nutritional support is evidenced by the increased serum albumin concentration on the seventh day of life (Hoffman et al., 2001).

\section{CONCLUSIONS}

In conclusion, rbST application prior to the induction of subclinical ketosis in pregnant ewes can reduce postpartum BHB concentrations and therefore prevent subclinical ketosis, as well as reduce liver overload, as evidenced by the decreased GGT levels during ketosis induction. Furthermore, pre-partum treatment with rbST increased lamb weight gain until the seventh week of age.

\section{REFERENCES}

ANDREWS, A.H.; HOLLAND-HOWES, V.E.; WILKINSON, J.I.D. Naturally occurring pregnancy toxaemiia in the ewe and treatment with recombinant bovine somatotropin. Small Ruminant Res., v.23, p.191-197, 1996

BALLOU, M.A.; GOMES, R.C.; JUCHEM, S.O.; DEPETERS, E.J. Effects of dietary supplemental fish oil during the peripartum period on blood metabolites and hepatic fatty acid compositions and total triacylglycerol concentrations of multiparous. J. Dairy Sci., v.92, p.657-669, 2009.

CALDEIRA, R.M. Monitoring the adequacy of feeding plan and nutritional status in ewes. Rev. Port. Cienc. Vet., v.100, p.125-139, 2005.

DANTE, P.D.L.; KAREN, L.H.O.; DIANE, M.H. et al. Effect of somatotropin treatment on lipogenesis, lipolysis, and related cellular mechanism in adipose tissue of lactating cows. J. Dairy Sci., v.78, p.17031712,1995

GULAY, M.S.; HAYEN, M.J.; LIBONI, M. et al. Low Doses of Bovine Somatotropin During the Transition Period and Early Lactation Improves Milk Yield, Efficiency of Production, and Other Physiological Responses of Holstein Cows. J. Dairy Sci., v.87, p.948-960, 2004.
HARMEYER, J.; SCHLUMBOHM, C. Pregnancy impairs ketone body disposal in late estating ewes: Implications for onset of pregnancy toxaemia. Res. Vet. Sci., v.81, p.254-264, 2006.

HARMEYER, J.; SCHLUMBOHM, C. Twinpregnancy increases susceptibility of ewes to hypoglycaemic stress and pregnancy toxaemia. Res. Vet. Sci., v.84, p.286-299, 2008.

HOFFMAN, P.C.; ESSER, N.M.; BAUMAN, L.M. et al. Effect of Dietary Protein on Growth and Nitrogen Balance of Holstein Heifers. J. Dairy Sci., v.84, p.843847,2001

MCGUFFEY, R.K.; BASSON, R.P.; SPIKE, T.E. Lactational response and body composition of cows receiving somatotropin and three ratios of forage to concentrate. J. Dairy Sci., v.74, p.3095-3102, 1991.

NATIONAL Reserch Council - NRC. Nutrient requirements of sheep. 6.ed. Washington DC.99 p.1985.

PAULETTI, P.; BAGALDO, A.R.; KINDLEIN, L. et al. IGF-I e IgG Séricos e nas Secreções Lácteas em Vacas Tratadas com rbST no Período Pré-Parto. Rev. Bras. Zootec., v.34, p.976-986, 2005.

PUTNAM, D.E.; VARGA, G.A.; DANN, H.M. Metabolic and production responses to dietary protein and exogenous somatotropin in late gestation dairy cows. J. Dairy Sci., v.82, p.982-995, 1999.

RUSSEL, A.J.F.; DONEY, J.M.; GUNN, R.G. Subjective assessment of body fat in live sheep. $J$. Agric. Sci., v.72, p.451-454, 1969.

SARGISON, N.D. Pregnancy toxaemia. In: AITKEN ID. Diseases of sheep. 4.ed. Oxford: Blackwell Publishing, v.1, p.359-363, 2007.

SCHNEIDER, A.; SCHWEGLER, E.; MONTAGNER P. et al. Effect of prepartum somatotropin injection in late pregnant Holstein heifers on metabolism, milk production and postpartum resumption of ovulation. Animal, v.6, p.935-940, 2011.

STATISTICAL ANALYSIS SYSTEM (SAS). Principles and Procedure of Statistics, $2^{\circ}$ ed. Mc Graw-Hill Inc. Carry NC. 1986.

STELWAGEN, K.; GRIEVE, D.G.; WALTON, J.S. et al. Effect of prepartum bovine somatotropin in primigravid ewes on mammogenesis, milk production, and hormone concentrations. J. Dairy Sci., v.76, p.992-1001, 1993. 